\title{
Yield, Quality and Micronutrients Uptake of Carrot (Daucus carota L.) and some Soil Properties as Affected by Organic Fertilizers and Elemental Sulphur Application
}

\author{
Wafaa H.M. \\ Department of Soils and Agricultural Chemistry, Faculty of \\ Agriculture (Saba Basha), Alexandria University, Alexandria, Egypt.
}

\begin{abstract}
FIELD experiment was conducted at the Experimental Farm Faculty of Agriculture, (Saba-Basha) - Alexandria University, during 2011 growing season to study the effect of four organic fertilizers (control, chicken manure, cattle manure and compost) and four rates of sulphur $\left(0,100,200\right.$ and $\left.400 \mathrm{~kg} \mathrm{~S} \mathrm{Fed}^{-1}\right)$ and their interactions on the yield (dry mass), quality (T.S.S, sugar and protein contents) and uptake of micronutrients $(\mathrm{Fe}, \mathrm{Cu}, \mathrm{Mn}$, and $\mathrm{Zn}$ ) of carrot (Daucus carota L.). After plant harvest, the soil $\mathrm{pH}$, EC and availability of $\mathrm{Fe}, \mathrm{Cu}, \mathrm{Zn}$ and $\mathrm{Mn}$ in soil were determined. These results showed that organic fertilizers increased significantly the dry mass and T.S.S, sugar, nitrogen concentrations and protein contents of carrots than that plants not received any fertilizer. The highest response was obtained with chicken manure followed by cattle manure and then compost. The organic fertilizers increased $\mathrm{Fe}$ and $\mathrm{Cu}$ uptake and the amounts of available $\mathrm{Fe}, \mathrm{Cu}, \mathrm{Zn}$ and $\mathrm{Mn}$ in soil compared with the control soil. On the other hand, organic fertilizers decreased $\mathrm{Mn}$ and $\mathrm{Zn}$ of carrot plant compared with control. Also, application of cattle manure and compost decreased significantly $\mathrm{pH}$ and EC of soil except with chicken manure.

Increasing sulphur application rates increased significantly the dry mass, T.S.S, sugar and protein content and micronutrients uptake by carrot. Also, application of elemental sulphur increased the soil $\mathrm{EC}$, available micronutrients and decreased soil $\mathrm{pH}$. The highest response of carrot depends substantially on the interactions of sulphur and organic fertilizer. The highest values of dry mass, total soluble solid, sugar and protein content and $\mathrm{Fe}$ and $\mathrm{Cu}$ uptake by plant roots were observed with application of chicken manure combined with sulphur at a rate $400 \mathrm{~kg} \mathrm{fed}^{-1}$. Also, $\mathrm{Cu}, \mathrm{Mn}$ and $\mathrm{Zn}$ availability in soil was observed with application of chicken manure combined with sulphur at a rate $400 \mathrm{~kg} \mathrm{fed}^{-1}$, while Fe available was observed with application of chicken manure combined with sulphur at a rate $100 \mathrm{~kg} \mathrm{fed}^{-1}$. Correlation analyses showed the influence of organic fertilizers and sulphur as important materials for improving the uptake of the $\mathrm{Cu}, \mathrm{Fe}, \mathrm{Mn}$ and $\mathrm{Zn}$ in caroot plant.
\end{abstract}

Keywords: Carrot, S-elemental, Compost, Chicken manure, Cattle manure, Micronutrients . 
Carrot is one of the vegetables produced by subsistence farmers because they are easy to grow and do not need an excess amounts of fertilizers (Allemann and Young, 2002). Carrot is also an excellent source of vitamins A, C, K, B1, B2, B6, calcium, dietary fiber and protein when it is eaten raw (salad), shredded, boiled or cooked as stew or soup (Atkins, 1999 and Mateljan, 2007). Although carrots are medium feeders, they require a fertile soil, which allows rapid uninterrupted growth. Application of organic fertilizers have numerous beneficial effects, which not only increase the crop yield but also improve soil fertility in terms of organic carbon and nitrogen content, permeability, balanced supply of nutrients, plant available water capacity and buildup of organic matter. In addition, they are known to improve rhizosphere ecosystem, suppress soil-borne phytopathogens, promote root growth and increased micronutrient uptake. Also, carrot plants need micronutrients for cell and chlorophyll production. From a physiological standpoint, the yield of carrot depends on the production and translocation of carbohydrates from the leaves to the roots. No clear recommendations exist for organic fertilizer application and since organic sources differ in their nutrient composition as well as the rate of nutrient release, farmers tend to apply either too little or too much organic fertilizer. Excessive organic fertilizer application rates contribute to soil pollution and that salts tend to accumulate in the soil and leaching of nutrients from the root profile occurs. Rembialkowska (2003) obtained greater yields with organic fertilized carrot than with inorganic fertilized carrot. The quality and quantity of applied fertilizers are key factors affecting the growth, yield, and quality of crops (Chang et al., 2010 and Marzouka \& Kassem, 2011). It is obvious that Egyptian soils suffer from high $\mathrm{pH}$ values, associated with marked reduction of micronutrients availability. Soil $\mathrm{pH}$ can be temporarily lowered by adding elemental sulfur. The effect of sulphur amendment on soil properties is directly associated with considerable variation on oxidation- reduction processes in soil. The oxidation of elemental sulphur to sulphate results in acidification of the soil. The acid produced from the oxidation process helps in reducing soil alkalinity (Cox and Koenig, 2010). Also, Sulphur is one of the essential elements needed for plant growth and development. It is immobile in plants and being a constituent of proteins, it is vital for the synthesis of the sulphur-containing amino acids - cysteine, cystine and methionine. The amino acids are indicators of the protein quality in plant (Scherer et al., 2008 and Abdallah et al., 2010).

The present investigation was conducted to evaluate the integrated effects of sulphur and organic fertilizers such as chicken manure, cattle manure and compost on the growth of carrot (Daucus carota L.) and soil chemical properties including soil $\mathrm{pH}, \mathrm{EC}$ and micronutrients $(\mathrm{Fe}, \mathrm{Cu}, \mathrm{Mn}$ and $\mathrm{Zn})$ availability at the plant harvest.

\section{Material and Methods}

\section{Experimental layout}

A field experiment was conducted at the Experimental Farm, Faculty of Agriculture (Saba-Basha), Alexandria University, during the growing season of 2011. The experimental soil was sampled at beginning of the growing season before the applications of organic fertilizers and sulphur. The analysis of the

Egypt. J. Soil Sci. 53, No. 4 (2013) 
collected soil samples $(0-30 \mathrm{~cm})$ was done for some physical and chemical properties according to the methods outlined in Page et al. (1982) and the data are shown in Table 1.

TABLE1. Some physical and chemical properties of the used soil .

\begin{tabular}{|l|c|c|c|}
\hline \multicolumn{1}{|c|}{ Particle distribution: } & & Nutrients available, $\mathbf{~ m g ~ k g}^{-1}$ & \\
\hline Sand, $\%$ & 20.55 & Kcl -extractable $(\mathrm{N})$ & 25.0 \\
\hline Silt, $\%$ & 32.14 & NH4-Ac- extractable $(\mathrm{k})$ & 85.0 \\
\hline Clay, $\%$ & 47.31 & $\mathrm{NaHCO}_{3}$ - extractable $(\mathrm{P})$ & 4.39 \\
\hline Texture & Clay loam & Morgan solution $\left(\mathrm{SO}_{4}{ }^{-2}\right)$ & 6.14 \\
\hline $\mathrm{pH}(1: 2.5)$ & 7.78 & DTPA-extractable $(\mathrm{Fe})$ & 2.29 \\
\hline $\mathrm{EC},\left(\mathrm{dS} \mathrm{m}^{-1}\right)(1: 2.5)$ & 3.13 & DTPA-extractable $(\mathrm{Cu})$ & 0.24 \\
\hline Total $\mathrm{CaCO}_{3} \%$ & 5.45 & DTPA-extractable $(\mathrm{Mn})$ & 1.10 \\
\hline Organic matter, $\%$ & 0.76 & DTPA-extractable $(\mathrm{Zn})$ & 0.5 \\
\hline
\end{tabular}

\section{Treatments}

Carrot (Daucus carota L.) seeds were sown directly at a depth of $1.5 \mathrm{~cm}$ with a spacing of $20 \mathrm{~cm}$ between rows. Thinning was done after 20 days from emergence to a final spacing of $5 \mathrm{~cm}$ between plants in the row. Carrots were harvested after 105 days from planting. Prior planting, Nitrogen at the rate of $110 \mathrm{mg} \mathrm{kg}^{-1}$ as $\mathrm{NH}_{4} \mathrm{NO}_{3}(33.5 \% \mathrm{~N})$, Phosphorus as calcium superphosphate $\left(15.5 \% \mathrm{P}_{2} \mathrm{O}_{5}\right)$ at the rate of $80 \mathrm{mg} \mathrm{kg}^{-1}$ and potassium as $\mathrm{KH}_{2} \mathrm{PO}_{4}\left(48 \% \mathrm{~K}_{2} \mathrm{O}\right)$ at the rate of $100 \mathrm{mg} \mathrm{kg}^{-1}$ were applied after thinning.

Four different organic fertilizers (control, chicken manure, cattle manure and compost) and four rates of elemental sulphur $\left(0,100,200\right.$ and $\left.400 \mathrm{~kg} \mathrm{fed}^{-1}\right)$ and their interactions were applied. After the harvest, the soil $\mathrm{pH}, \mathrm{EC}$ and availability of $\mathrm{Fe}, \mathrm{Cu}, \mathrm{Mn}$ and $\mathrm{Zn}$ in soil were determined.

The chemical characteristic of the organic fertilizers were determined according to the methods of Page et al. (1982) and presented in Table 2.

TABLE 2. Some chemical properties of the organic fertilizers .

\begin{tabular}{|l|c|c|c|}
\hline Property & Chicken manure & cattle manure & Compost \\
\hline $\mathrm{pH}(1: 2)$ & 7.71 & 7.19 & 7.58 \\
\hline $\mathrm{EC}(1: 1) \mathrm{dSm}$ & -1 & 2.42 & 3.98 \\
\hline Organic carbon & 10.74 & 24.79 & 19.57 \\
\hline Total $\mathrm{N}(\%)$ & 40.75 & 2.10 & 0.94 \\
\hline Total $\mathrm{P}(\%)$ & 3.36 & 0.96 & 0.78 \\
\hline Total $\mathrm{K}(\%)$ & 2.9 & 2.3 & 1.15 \\
\hline $\mathrm{C} / \mathrm{N} \mathrm{ratio}$ & 3.4 & $11.8: 1$ & $20.8: 1$ \\
\hline $\mathrm{So}_{4}{ }^{-2}$ & $12.1: 1$ & 14.01 & 13.48 \\
\hline Total Fe $\left(\mathrm{mgkg}^{-1}\right)$ & 16.32 & 903 & 609 \\
\hline Total $\mathrm{Cu}\left(\mathrm{mgkg}^{-1}\right)$ & 990 & 55 & 45.7 \\
\hline Total $\mathrm{Mn}\left(\mathrm{mgkg}^{-1}\right)$ & 87.2 & 170 & 94 \\
\hline Total $\mathrm{Zn}\left(\mathrm{mgkg}^{-1}\right)$ & 200 & 78 & 47 \\
\hline
\end{tabular}




\section{Experimental design}

The experimental design was split plot with three replicates. The main plots were divided to the different organic fertilizers (control, compost, Cattle and chicken manure) at rate 2.0 ton $\mathrm{fed}^{-1}$. The sup plots assigned for elemental sulphur which added as follows; $S_{0}$ (without sulphur), $S_{1}\left(100 \mathrm{kgfed}^{-1}\right), \mathrm{S}_{2}(200$ $\left.\mathrm{kgfed}^{-1}\right)$ and $\mathrm{S}_{3}\left(400 \mathrm{kgfed}^{-1}\right)$.Thus, there were $4 \mathrm{x} 4=16$ treatment combinations, replicated three times numbering a total of 48 experimental units. The applied organic manure and sulphur were mixed with the surface $30 \mathrm{~cm}$ soil layer of each plot.

\section{Sampling and analysis of plants}

A sample of ten carrots (roots) plot $^{-1}$ were harvested, placed in clean paper bags, labeled and sent to the laboratory for determination of the dry weight. The chemical analysis of sugar content per $100 \mathrm{~g}$ fresh weight. A drop of juice extracted from root of carrot was used to determine TSS using hand refractometer (Niewhof et al., 1973). Samples of plant were washed by tap water then by distilled water and oven dried at $75^{\circ} \mathrm{C}$ for $48 \mathrm{hr}$. The roots were finely ground and stored for chemical analysis. The oven dried plant material was wet digested by using concentrate of $\mathrm{H}_{2} \mathrm{SO}_{4} / \mathrm{H}_{2} \mathrm{O}_{2}$ (Lowther, 1980) and Fe, $\mathrm{Mn}, \mathrm{Zn}$ and $\mathrm{Cu}$ were measured by Atomic Absorption Spectrophotometer (Perkin Elmer-3300) according to Chapman and Pratt (1978). Nitrogen in roots of carrot was estimated by the modified microkjedhal method as outlined by Jackson (1973).Total protein (\%) was calculated by multiplying per cent $\mathrm{N}$ with factor 6.25 (Tai and Young, 1974).

\section{Sampling and analysis of soil after harvesting}

Soil samples, representing all the studied treatments were taken at the harvest time from the depth of $0-15 \mathrm{~cm}$. The chemical properties including $\mathrm{pH}, \mathrm{EC}$ and available trace elements of soil were determined as outlined by Page et al. (1982).

\section{Data analysis}

Data were statistically analyzed using Costat Software (Steel and Torrie, 1980).

\section{Results and discussion}

\section{The studied soil}

The results of the soil analysis before planting (Table 1) showed that the soil was clay loam in texture. Even though the $\mathrm{pH}$ was alkaline $(\mathrm{pH} 7.71)$. The amounts of available microelements were in the range of low availability to plants. The critical values of the tested micronutrient were $2.5-4.5,0.75,5.0$ 9.0 and 0.5-1.0 ppm for $\mathrm{Fe}, \mathrm{Cu}, \mathrm{Mn}$ and $\mathrm{Zn}$ DTPA extractable, respectively according to Lindsay and Norvell (1978). The amounts of available phosphorus of the soil was below the range of high availability (42.29 ppm) according to Landon (1991). However, the results showed that total nitrogen and organic matter of the soil were low. This finding further signifies that the soil requires external application of nutrients for high growth and yield of the crop.

Egypt. J. Soil Sci. 53, No. 4 (2013) 
The studied organic fertilizers

Application of organic fertilizers have numerous beneficial effects, it is not only increase the crop yield but also improve soil fertility in terms of organic carbon $(40.75,24.79$ and $19.57 \%)$ and nitrogen $(\mathrm{N})$ content $(3.36,2.10$ and $0.94 \%$, respectively ) for chicken, cattle manure and compost, respectively.

Yield component, quality and micronutrients uptake of carrot as affected by the organic fertilizers and sulphur rates treatments and there interactions are given in Tables 3, 4 and 5.

\section{Yield component}

Effect of organic fertilizer

Application of chicken manure resulted in carrot with dry mass significantly greater than all the other organic fertilizers (Table 3). The dry mass of carrot treated with compost $(8.07 \mathrm{~g})$ or cattle manure $(9.51 \mathrm{~g})$ was significantly lower than that treated with chicken manure $(11.45 \mathrm{~g})$. The difference in nutrient content of organic fertilizers (Table 2) has influence of significantly the yield produced. The nutrients from chicken manure might be more available to the crop compared to the use froms cattle manure and compost. This was confirmed by Boyhan et al. (1999) and Levy \& Taylor (2003).

Zakaria and Vimala (2002) also reported higher yields with chicken manure than with inorganic fertilizer for lettuce and tomatoes. The high nutrient content of chicken manure and cattle manure has contributed to a higher yield (dry mass) of carrot than that of vegetables treated with poultry manure (Suojala, 2003). It seems from Table 2 that compost releases nutrients slower than chicken and cattle manure. This could be due to that the used compost has been derived from various organic materials such as plant and animal residues that need to be broken down by microorganisms before it can release nutrients and therefore it is known to release nutrients slower than other organic fertilizer sources (Rosen and Bierman, 2005).

\section{Effect of sulphur}

Table 3 showed that the dry mass of carrot had increased significantly with the increase of sulphur fertilizer rates. The highest sulphur rate $\left(400 \mathrm{~kg} \mathrm{fed}^{-1}\right)$ produced carrot dry mass significantly more as compared to those plants that received control or sulphur at a rate of 100 and $200 \mathrm{~kg} \mathrm{fed}^{-1}$. The differences between 100 and $200 \mathrm{~kg} \mathrm{fed}^{-1}$ were found to be not-significant.

\section{Yield quality}

Effect of organic fertilizer

Table 3 showed that the data shows that the organic fertilizers have a significant effect on total soluble solids, sugar contents and protein. as chicken, cattle manure and compost were applied, these parameters of carrots tended to be greater than where no fertilizer was applied. In contrast with these results other researchers reported that the total soluble solids of carrots (Rembialkowska, 2003) and (Xu et al., 2003) that received organic fertilizer was greater than those that 
received inorganic fertilizer. Nitrogen concentration and Protein contents of carrot also has been influenced significantly by organic fertilizers and the highest of protein contents were observed with cattle or chicken manure (Tables 3 and 4).

\section{Effect of sulphur}

Table 3 showed that in the case of sulphur treatment, the total soluble, solid, sugar contents and protein content of carrots tended to be greater than where no sulphur was applied. The total soluble solid, sugar contents and protein contents significantly affected by sulphur application to soil. The highest of these parameters were observed with $\mathrm{S}_{400}$ treatment.

\section{Nutrients uptake}

Effect of organic fertilizer

Application of organic fertilizers increased significantly $\mathrm{Fe}$ and $\mathrm{Cu}$ uptakes by roots of carrot compared with the control (Table 3$)$. The highest Fe $(4.70 \mathrm{mg}$ $\left.\mathrm{kg}^{-1}\right)$ and $\mathrm{Mn}\left(0.76 \mathrm{mg} \mathrm{kg}^{-1}\right)$ uptake were observed by application of chicken manure, whereas the lowest was observed by the control treatment, but the differences between compost and cattle manure were found to be nonsignificant. The effect of organic fertilizers on Fe uptake by roots of carrot, could be due to that the organic carbon acts as a source of energy for soil microorganism, which upon mineralization releases organic acids that decreased soil $\mathrm{pH}$ and improves the availability of Fe (Bokhtiar and Sakurai, 2005). Smith (1993) and Worthington (1998) reported higher iron content in organic grown vegetables than inorganic grown vegetables. Data also in Table 3 showed that, the $\mathrm{Mn}$ and $\mathrm{Zn}$ uptakes by roots of carrot were decreased by organic fertilizers as compared with control, the differences between compost and cattle manure were found to be non-significant.

\section{Effect of sulphur}

The effects of elemental sulphur on $\mathrm{Fe}, \mathrm{Cu}, \mathrm{Mn}$ and $\mathrm{Zn}$ uptake of carrot are given in Table 4. The $\mathrm{Fe}, \mathrm{Cu}, \mathrm{Mn}$ and $\mathrm{Zn}$ uptakes by roots of carrot were significantly affected by sulphur application to soil. Kaya et al. (2009) reported that increased application of sulphur and sulphur-containing waste led to a significant increase in copper content of plants.

Nutrients uptake and dry mass of carrot tuber were significantly affected by $\mathrm{S}$ fertilization (Table 3). The uptake of $\mathrm{Fe}, \mathrm{Cu}, \mathrm{Mn}$ and $\mathrm{Zn}$ correlated positively with dry matter for the different sulphur levels. The relation is expressed by polynomial equations as follows:

$$
\begin{array}{ll}
\text { Fe uptake: } \mathrm{Y}=0.20 \mathrm{x}^{2}+1.58 \mathrm{x} & \mathrm{R}^{2}=0.85 \\
\text { Cu uptake: } \mathrm{Y}=-18.12 \mathrm{x}^{2}+28.73 \mathrm{x} & \mathrm{R}^{2}=0.98 \\
\text { Mn uptake: } \mathrm{Y}=1.00 \mathrm{x}^{2}+7.26 \mathrm{x} & \mathrm{R}^{2}=0.77 \\
\text { Zn uptake: } \mathrm{Y}=1.64 \mathrm{x}^{2}+0.29 \mathrm{x} & \mathrm{R}^{2}=0.83
\end{array}
$$

Egypt. J. Soil Sci. 53, No. 4 (2013) 
YIELD QUALITY AND MICRONUTRIENTS UPTAKE OF CARROT ...

TABLE 3. Dry mass, T.S.S, sugar and protein content of root carrot as affected by organic fertilizers and sulphur levels .

\begin{tabular}{|c|c|c|c|c|c|}
\hline $\begin{array}{c}\text { Organic } \\
\text { fertilizers }(\%)\end{array}$ & $\begin{array}{c}\text { Sulphur levels } \\
\left(\mathrm{kg} \mathrm{fed}^{-1}\right)\end{array}$ & $\begin{array}{l}\text { Root dry } \\
\text { mass (g) }\end{array}$ & $\begin{array}{c}\text { T.S.S } \\
(\%)\end{array}$ & $\begin{array}{c}\text { Total sugar/ } \\
100 \mathrm{~g} \text { f.w }\end{array}$ & $\begin{array}{c}\text { Protein } \\
(\%)\end{array}$ \\
\hline \multirow[t]{4}{*}{ control } & 0 & 5.12 & 26.97 & 2.697 & 9.63 \\
\hline & 1 & 7.16 & 29.67 & 2.967 & 15.73 \\
\hline & 2 & 7.74 & 37.43 & 3.743 & 17.10 \\
\hline & 3 & 9.04 & 37.87 & 3.453 & 17.23 \\
\hline \multirow[t]{4}{*}{ Compost } & 0 & 6.18 & 48.63 & 4.093 & 18.46 \\
\hline & 1 & 7.75 & 51.33 & 4.850 & 19.58 \\
\hline & 2 & 8.53 & 51.80 & 5.133 & 19.40 \\
\hline & 3 & 9.82 & 55.90 & 6.367 & 18.96 \\
\hline \multirow[t]{4}{*}{ Cattle } & 0 & 7.20 & 40.93 & 4.390 & 20.94 \\
\hline & 1 & 9.57 & 39.83 & 5.200 & 23.81 \\
\hline & 2 & 9.99 & 53.43 & 5.343 & 23.33 \\
\hline & 3 & 11.28 & 54.67 & 6.500 & 27.79 \\
\hline \multirow[t]{4}{*}{ chicken } & 0 & 7.75 & 48.50 & 4.637 & 22.21 \\
\hline & 1 & 10.44 & 53.87 & 5.483 & 22.56 \\
\hline & 2 & 11.66 & 51.13 & 5.640 & 24.40 \\
\hline & 3 & 15.94 & 56.37 & 7.590 & 28.90 \\
\hline \multicolumn{6}{|c|}{ Mean effect of organic fertilizers } \\
\hline Control & & $7.26 \mathrm{c}$ & $32.98 b$ & $3.21 \mathrm{~b}$ & $14.88 \mathrm{c}$ \\
\hline Compost & & $8.07 \mathrm{bc}$ & $51.92 \mathrm{a}$ & $5.11 \mathrm{a}$ & $19.06 \mathrm{~b}$ \\
\hline Cattle & & $9.51 \mathrm{~b}$ & $50.97 \mathrm{a}$ & $5.36 \mathrm{a}$ & $23.88 \mathrm{a}$ \\
\hline chicken & & $11.45 \mathrm{a}$ & $52.47 \mathrm{a}$ & $5.84 \mathrm{a}$ & $24.44 \mathrm{a}$ \\
\hline \multicolumn{2}{|c|}{ LSD } & 1.66 & 0.59 & 0.57 & 0.33 \\
\hline \multicolumn{6}{|c|}{ Mean effect of sulphur levels } \\
\hline & 0 & $6.56 \mathrm{c}$ & $41.26 \mathrm{~b}$ & $3.65 \mathrm{c}$ & $17.75 \mathrm{c}$ \\
\hline & 1 & $8.73 \mathrm{~b}$ & $47.43 \mathrm{a}$ & $4.62 b$ & $20.38 b$ \\
\hline & 2 & $9.48 \mathrm{~b}$ & $48.45 \mathrm{a}$ & $4.92 \mathrm{~b}$ & $21.00 \mathrm{~b}$ \\
\hline & 3 & $11.52 \mathrm{a}$ & $51.20 \mathrm{a}$ & $5.97 \mathrm{a}$ & $23.19 \mathrm{a}$ \\
\hline \multicolumn{2}{|c|}{$\begin{array}{l}\text { LSD } \\
\end{array}$} & 0.90 & 0.45 & 0.39 & 0.21 \\
\hline \multicolumn{2}{|c|}{$\mathrm{O}$} & $* *$ & $* *$ & $* *$ & $* *$ \\
\hline \multirow{2}{*}{\multicolumn{2}{|c|}{$S$}} & $* *$ & $* *$ & $* *$ & $* *$ \\
\hline & $\mathrm{O} \times \mathrm{S}$ & $*$ & n.s & $* *$ & $* *$ \\
\hline
\end{tabular}

\section{Interaction}

The analysis of variance was carried to determine the effect of different organic fertilizers and sulphur application rates on dry mass, TSS, Fe, Zn, Mn and $\mathrm{Cu}$ uptakes by roots of carrot are given in Table 3 and 4. Dry mass, sugar, protein contents, $\mathrm{Fe}, \mathrm{Zn}, \mathrm{Mn}$ and $\mathrm{Cu}$ uptakes by roots were significantly affected by sulphur and organic fertilizers application. The highest values of dry mass, total soluble solid, sugar and protein contents and $\mathrm{Fe}$ and $\mathrm{Cu}$ uptakes by roots were observed with the application of chicken manure combined with sulphur at rate $400 \mathrm{~kg} \mathrm{fed}^{-1}$. As shown in Table 3 quality components (Total soluble solid content of carrots) did not significantly affected by organic fertilizers and sulphur treatments. 
TABLE 4. $\mathbf{N}$ content and micronutrients uptake of carrot plant as affected organic fertilizers and sulphur levels .

\begin{tabular}{|c|c|c|c|c|c|c|}
\hline \multirow{2}{*}{$\begin{array}{c}\text { Organic } \\
\text { fertilizers } \\
(\%)\end{array}$} & \multirow{2}{*}{$\begin{array}{l}\text { Sulphur levels } \\
\quad\left(\mathrm{kg} \mathrm{fed}^{-1}\right)\end{array}$} & \multirow{2}{*}{$\mathbf{N}(\%)$} & $\mathbf{F e}$ & $\mathbf{C u}$ & Mn & Zn \\
\hline & & & \multicolumn{4}{|c|}{ Uptake $\left(\mathrm{mgkg}^{-1}\right)$} \\
\hline \multirow[t]{4}{*}{ control } & 0 & 1.540 & 2.63 & 0.22 & 1.01 & 1.01 \\
\hline & 1 & 2.517 & 2.77 & 0.28 & 2.73 & 3.06 \\
\hline & 2 & 2.737 & 3.53 & 0.32 & 2.61 & 3.61 \\
\hline & 3 & 2.757 & 3.20 & 0.47 & 2.73 & 3.70 \\
\hline \multirow[t]{4}{*}{ Compost } & 0 & 2.953 & 2.80 & 0.21 & 0.99 & 0.99 \\
\hline & 1 & 3.133 & 3.70 & 0.34 & 1.38 & 1.38 \\
\hline & 2 & 3.103 & 3.70 & 0.39 & 1.55 & 1.55 \\
\hline & 3 & 3.033 & 4.00 & 0.44 & 1.64 & 1.64 \\
\hline \multirow[t]{4}{*}{ Cattle } & 0 & 3.350 & 2.73 & 0.26 & 0.97 & 0.97 \\
\hline & 1 & 3.810 & 4.30 & 0.46 & 1.37 & 1.37 \\
\hline & 2 & 3.733 & 4.33 & 0.48 & 1.44 & 1.44 \\
\hline & 3 & 4.447 & 4.53 & 0.64 & 1.46 & 1.46 \\
\hline \multirow[t]{4}{*}{ chicken } & 0 & 3.553 & 3.40 & 0.28 & 1.01 & 1.01 \\
\hline & 1 & 3.610 & 4.87 & 0.64 & 1.90 & 2.57 \\
\hline & 2 & 3.903 & 5.17 & 0.85 & 2.07 & 3.07 \\
\hline & 3 & 4.623 & 5.37 & 1.29 & 2.10 & 3.13 \\
\hline \multicolumn{7}{|c|}{ Mean effect of organic fertilizers } \\
\hline Control & & $2.38 \mathrm{c}$ & $3.30 \mathrm{c}$ & $0.32 b$ & $2.27 \mathrm{a}$ & $2.85 a$ \\
\hline Compost & & $3.05 \mathrm{~b}$ & $3.55 b$ & $0.34 b$ & $1.39 \mathrm{c}$ & $1.39 \mathrm{c}$ \\
\hline Cattle & & $3.82 \mathrm{a}$ & $3.98 b$ & $0.46 b$ & $1.31 \mathrm{c}$ & $1.31 \mathrm{c}$ \\
\hline chicken & & $3.91 \mathrm{a}$ & $4.70 \mathrm{a}$ & $0.76 a$ & $1.78 \mathrm{~b}$ & $2.44 \mathrm{~b}$ \\
\hline \multicolumn{2}{|c|}{ LSD } & 0.33 & 0.51 & 0.14 & 0.11 & 0.31 \\
\hline \multicolumn{7}{|c|}{ Mean effect of sulphur levels } \\
\hline & 0 & $2.84 \mathrm{c}$ & $2.89 \mathrm{c}$ & $0.24 \mathrm{~d}$ & $0.99 \mathrm{c}$ & $1.99 \mathrm{c}$ \\
\hline & 1 & $3.26 \mathrm{~b}$ & $3.90 \mathrm{~b}$ & $0.43 c$ & $1.85 b$ & $2.10 \mathrm{~b}$ \\
\hline & 2 & $3.36 \mathrm{~b}$ & $4.18 \mathrm{a}$ & $0.51 b$ & $1.72 \mathrm{ab}$ & $2.42 \mathrm{a}$ \\
\hline & 3 & $3.71 \mathrm{a}$ & $4.28 \mathrm{a}$ & $0.71 \mathrm{a}$ & $1.99 \mathrm{a}$ & $2.49 \mathrm{a}$ \\
\hline \multicolumn{2}{|c|}{ LSD } & 0.21 & 0.25 & 0.08 & 0.09 & 0.23 \\
\hline \multicolumn{2}{|c|}{$\mathrm{O}$} & $* *$ & $* *$ & $* *$ & $* *$ & $* *$ \\
\hline \multicolumn{2}{|c|}{ S } & $* *$ & $* *$ & $* *$ & $* *$ & $* *$ \\
\hline \multicolumn{2}{|c|}{$\mathrm{O} \times \mathrm{S}$} & $* *$ & $* *$ & $* *$ & $* *$ & $* *$ \\
\hline
\end{tabular}

\section{Soil properties after of plant harvest}

Effect of organic fertilizer

The chemical properties: PH, EC and available trace elements of the soil after harvesting carrot as affected by organic fertilizers and sulphur treatments and there interaction are shown in Table 5.

Regarding to the effects of organic fertilizers on soil $\mathrm{pH}$, it is clear from Table 5 that the addition of organic fertilizers reduce the soil $\mathrm{pH}$. The relative decreases of $\mathrm{pH}$ with respect to control were 3.10, 6.19 and $2.71 \%$ for compost, cattle, chicken manure, respectively. The decomposition of organic fertilizers in soil and continuously production of organic acids, associated with surplus increases of $\mathrm{CO}_{2}$ production and hydrogen ion $(\mathrm{H}+)$, that might contribute of

Egypt. J. Soil Sci. 53, No. 4 (2013) 
soil acidification (Walker et al., 2004). On the other hand, chicken manure increased soil $\mathrm{pH}$ compared with compost and Cattle. This increase in soil $\mathrm{pH}$ with chicken manure, were also reported in other studies (Pitman and Singh, 1993). The mechanism responsible for this increase in soil $\mathrm{pH}$ was due to ion exchange reactions which occur when terminal $\mathrm{OH}^{-}$of $\mathrm{Al}$ or $\mathrm{Fe}^{2+}$ hydroxyl oxides are replaced by organic anions which are decomposed products of the manure such as malate, citrate and tartrate (Eshoo and Bell, 1992, Pocknee and Summer, 1997 and Hue \& Amiens, 1989). The ability of chicken manure to increase soil $\mathrm{pH}$ was also attributable to the presence of basic cations in the chicken manure released upon microbial decarboxylation (Natsher and Schwetnmann, 1991).

Table 5 showed that the EC values of soil were decreased significantly due to the addition of Cattle manure and compost as compared with control. The calculated percentage reductions were 23.70 and $10.62 \%$ for compost and Cattle manure, respectively. This could be due to the role of organic substances in improving soil aggregation and water movement which enhance leaching the excessive soluble salts. On the other hand, EC value of soil was increased significantly due to the addition of chicken manure as compared with the control. This could be due to the high EC of chicken manure which is proportionally high (Table 2).

\section{Effect of sulphur}

The addition of sulphur induced variable reduction on soil $\mathrm{pH}$ (Table 5) depending on its application rates. The relative decreases of $\mathrm{pH}$ with respect to the control were 1.97 and $3.41 \%$ for 200 and $400 \mathrm{~kg}_{\mathrm{S}} \mathrm{fed}^{-1}$, respectively. The highest decrease of soil $\mathrm{pH}$ occurred by the $\mathrm{S}_{400}$ treatment. Elemental sulphur is biologically oxidized to $\mathrm{H}_{2} \mathrm{SO}_{4}$ in soil under aerobic conditions. The oxidation of $\mathrm{S}$ to $\mathrm{H}_{2} \mathrm{SO}_{4}$ is particularly beneficial in alkaline soils to reduce $\mathrm{pH}$, make micronutrients more available and reclaim soils (Orman and Kaplan, 2011).

Soil EC was significantly increased by sulphur application (Table 5). This effect was particularly significant with the highest application sulphur rate in the soil sampling period. The calculated increased were $35.71,42.18$ and $51.02 \%$ with 100,200 and $400 \mathrm{~kg} \mathrm{~S} /$ fed application rates, respectively. This increase may be due to the acidity produce through oxidation of $\mathrm{S}$ by micro-organism's.

A significant positive correlation between the EC values of the soils and sulphur application rates is found according to the formula:

$$
\mathrm{y}=223.04 \mathrm{x}-692.08 \quad \mathrm{R}^{2}=0.74
$$

Orman and Kaplan (2009) reported a significant positive correlation between the $\mathrm{SO}_{4}=-\mathrm{S}$ content and electrical conductivity (EC) of tomato greenhouse soils.

According to these data, the generated soil salinity was high with increasing sulphur applications, which indicates that plants might be subjected to high salinity problems. High rates of elemental sulphur should be avoided, especially in soils with high EC level. Soil properties (especially EC and $\mathrm{pH}$ ) and 
cultivated plant species should be taken into consideration in the recommendations for sulphur application to soils. Previous studies indicated that while the soil $\mathrm{pH}$ was decreased, soil EC was increased in soil by sulphur Orman and Kaplan (2011).

The present study was evaluated with our previous studies, it was concluded that initial soil EC before sulphur treatments is highly important. Therefore, this should be taken into consideration when making recommendation for sulphur applications to lower $\mathrm{pH}$ of soils, especially of high salt content. Non - saline soil may become slightly saline and also, a slightly saline soil may become moderately or highly saline due to sulphur applications.

TABLE 5 • pH, EC and micronutrients available of soil as affected organic fertilizers and sulphur levels .

\begin{tabular}{|c|c|c|c|c|c|c|c|}
\hline \multirow{2}{*}{$\begin{array}{c}\text { Organic } \\
\text { fertilizers }\end{array}$} & \multirow{2}{*}{$\begin{array}{l}\text { Sulphur } \\
\text { levels } \\
\left(\mathrm{kg} \mathrm{fed}^{-1}\right)\end{array}$} & \multirow{2}{*}{ pH } & \multirow{2}{*}{$\begin{array}{c}\mathrm{EC} \\
\left(\mathrm{dsm}^{-1}\right)\end{array}$} & $\mathbf{F e}$ & $\mathbf{C u}$ & Mn & Zn \\
\hline & & & & \multicolumn{4}{|c|}{ Available (mgkg $\left.{ }^{-1}\right)$} \\
\hline \multirow[t]{4}{*}{ control } & 0 & 7.96 & 2.78 & 8.67 & 0.68 & 2.07 & 2.56 \\
\hline & 1 & 7.79 & 4.39 & 12.50 & 1.44 & 2.38 & 2.95 \\
\hline & 2 & 7.72 & 4.42 & 13.47 & 1.73 & 2.50 & 3.54 \\
\hline & 3 & 7.52 & 4.62 & 14.55 & 1.76 & 3.17 & 3.13 \\
\hline \multirow[t]{4}{*}{ Compost } & 0 & 7.72 & 2.65 & 12.70 & 0.82 & 3.70 & 5.45 \\
\hline & 1 & 7.79 & 2.83 & 13.37 & 1.89 & 3.90 & 5.45 \\
\hline & 2 & 7.59 & 3.26 & 13.60 & 1.93 & 4.20 & 5.05 \\
\hline & 3 & 7.07 & 3.60 & 13.84 & 1.93 & 4.57 & 6.44 \\
\hline \multirow{4}{*}{ Cattle } & 0 & 7.45 & 2.86 & 15.66 & 1.60 & 4.67 & 4.39 \\
\hline & 1 & 7.15 & 3.77 & 15.66 & 1.70 & 4.80 & 5.35 \\
\hline & 2 & 7.22 & 3.77 & 16.57 & 1.96 & 4.93 & 5.18 \\
\hline & 3 & 7.25 & 4.08 & 16.76 & 2.03 & 5.00 & 6.48 \\
\hline \multirow{4}{*}{ chicken } & 0 & 7.79 & 3.47 & 16.76 & 2.03 & 5.23 & 4.61 \\
\hline & 1 & 7.82 & 4.97 & 17.30 & 2.06 & 5.43 & 4.95 \\
\hline & 2 & 7.28 & 5.27 & 16.57 & 2.06 & 5.47 & 5.60 \\
\hline & 3 & 7.15 & 5.48 & 15.66 & 2.22 & 5.53 & 7.82 \\
\hline \multicolumn{8}{|c|}{ Mean effect of organic fertilizers } \\
\hline Control & & $7.75 a$ & $4.05 \mathrm{~b}$ & $13.44 b$ & $1.28 \mathrm{~b}$ & $3.91 b$ & $4.25 \mathrm{c}$ \\
\hline Compost & & $7.51 \mathrm{~b}$ & $3.09 \mathrm{~d}$ & $14.52 \mathrm{a}$ & $1.77 \mathrm{a}$ & $4.12 b$ & $4.67 b$ \\
\hline Cattle & & $7.27 \mathrm{c}$ & $3.62 \mathrm{c}$ & $15.15 \mathrm{a}$ & $1.92 \mathrm{a}$ & $4.27 \mathrm{ab}$ & $4.84 b$ \\
\hline chicken & & $7.54 \mathrm{~b}$ & $4.80 \mathrm{a}$ & $15.28 \mathrm{a}$ & $1.98 \mathrm{a}$ & $4.56 \mathrm{a}$ & $5.97 \mathrm{a}$ \\
\hline \multicolumn{2}{|c|}{ LSD } & 0.19 & 0.09 & 0.8 & 0.25 & 0.31 & 0.39 \\
\hline \multicolumn{8}{|c|}{ Mean effect of sulphur levels } \\
\hline & 0 & $7.62 \mathrm{a}$ & $2.94 \mathrm{~d}$ & $12.30 \mathrm{c}$ & $1.40 \mathrm{c}$ & $2.52 \mathrm{~d}$ & $3.21 \mathrm{~b}$ \\
\hline & 1 & $7.62 \mathrm{a}$ & $3.99 \mathrm{c}$ & $13.37 b$ & $1.64 \mathrm{~b}$ & $4.09 \mathrm{c}$ & $5.11 \mathrm{a}$ \\
\hline & 2 & $7.47 \mathrm{a}$ & $4.18 b$ & $16.16 \mathrm{a}$ & $1.82 \mathrm{~b}$ & $4.85 b$ & $5.35 \mathrm{a}$ \\
\hline & 3 & $7.36 \mathrm{a}$ & $4.44 \mathrm{a}$ & $16.57 \mathrm{a}$ & $2.09 \mathrm{a}$ & $5.41 \mathrm{a}$ & $5.84 \mathrm{a}$ \\
\hline \multicolumn{2}{|c|}{ LSD } & 0.22 & 0.11 & 0.1 & 0.24 & 0.40 & 0.57 \\
\hline \multicolumn{2}{|l|}{$\mathrm{O}$} & $* *$ & $* *$ & $* *$ & $* *$ & $* *$ & $* *$ \\
\hline \multicolumn{2}{|l|}{ S } & $*$ & $* *$ & ** & $* *$ & $* *$ & $* *$ \\
\hline \multicolumn{2}{|l|}{$\mathrm{O} \times \mathrm{S}$} & * & $* *$ & $* *$ & $*$ & n.s & $*$ \\
\hline
\end{tabular}

Egypt. J. Soil Sci. 53, No. 4 (2013) 


\section{Interaction}

Application of organic matter as chicken manure, cattle manure and compost can be used to low the $\mathrm{pH}$ of soils because organic matter decomposes. Elemental sulphur will assist organic matter in reducing soil $\mathrm{pH}$ in soils.

Application of organic fertilizers with sulphur caused high EC soils and decreased $\mathrm{pH}$ soils. The results on Table 5 showed that the effects of the different treatments and their interactions were significant on the change in $\mathrm{pH}$. This was probably because the oxidation action of organic materials. Thus, producing more sulphuric acid and hence significantly reduced soil $\mathrm{pH}$. Compost organic material produced more sulphuric acid (had the lowest $\mathrm{pH}$ values) than the soils amended with the other organic materials. It is important to note that the decomposition of organic materials produced hydrogen ions that may have also contributed to reduction of the soil $\mathrm{pH}$. The highest decrease of soil $\mathrm{pH}$ occurred by the $\mathrm{S}_{400}$ compost treatment. The soil treated with organic amendments had lower $\mathrm{pH}$ values than those of the control. It was found that soil EC was significantly increased by adding of sulphur rates with organic fertilizers as compared with organic fertilizers treated plots (Zane and Basil, 1980). The possible explanation for increasing EC may be due to the large quantities of soluble salts and $\mathrm{HCO}_{3}^{-}$contained in the manure compost (Wong et al., 1998).

\section{Nutrient elements available}

Effect of organic fertilizer

Table 5 showed that, adding organic fertilizers to soil leads to a significant increase in available $\mathrm{Fe}, \mathrm{Cu}, \mathrm{Mn}$ and $\mathrm{Zn}$ in soil. The production of organic and inorganic acids during the degradation of organic fertilizers as well have a contribution in decreasing soil $\mathrm{pH}$ and chelating ions, leading to increase in available amounts of elements in the rizosphere zone. Cattle manure, chicken manure and compost significantly increased $\mathrm{Fe}$ and $\mathrm{Cu}$ content of soil as compared to the control soil (Table 5).The application of organic fertilizers increased the availability of $\mathrm{Fe}$ and $\mathrm{Cu}$ in the soil. As shown in Table 5, the amounts of available $\mathrm{Mn}$ and $\mathrm{Zn}$ in soils increased with organic fertilizers application. The highest values of trace elements $(15.28,1.98,4.56$ and $5.97 \mathrm{mg}$ $\mathrm{kg}^{-1}$ for $\mathrm{Fe}, \mathrm{Cu}, \mathrm{Mn}$ and $\mathrm{Zn}$, respectively) were observed by application chicken manure. This could be attributed to the initially high content of total trace elements in chicken manure. Rasoli and Forghani (2006) also reported that different organic fertilizers influenced the zinc and Mn content of the soil. They observed that farmyard manure applied for 1 year on maize, increased the zinc content significantly.

\section{Effect of sulphur}

Data of DTPA- extractable trace elements in soil as affected by the sulphur application are presented in Table 5. The highly significant increases in Fe, Mn, $\mathrm{Cu}$ and $\mathrm{Zn}$ values were found in soil at harvesting carrot as a result of increasing sulphur levels. Kaya et al. (2009) reported that the application of 
sulfur and sulfur-containing waste resulted in decrease in soil $\mathrm{pH}$, but it also increased the concentrations of nutrients available to plants, such as $\mathrm{Zn}, \mathrm{Cu}$ and Mn. Sulphur decreased soil $\mathrm{pH}$ and increases EC of soil, availability and mobility of heavy metals (Martinez and Motto, 2000 and Cui et al., 2004).

Decreases in values of soil $\mathrm{pH}$ were accompanied by increases in the extractable $\mathrm{Fe}$ and its availability to plants. Fe is also strongly affected by oxidation-reduction reactions which largely depend on the soil moisture content (Kabata-Pendias, 2004 and Nube \& Voortman, 2006).

Sulphur fertilization had significant effect on changes in the $\mathrm{Cu}$ content of soil. This could result from changes in soil $\mathrm{pH}$. In a study carried out by Takáč et al. (2009), the content of mobile $\mathrm{Cu}$ in the soil was not significantly affected by soil $\mathrm{pH}$. Soil $\mathrm{pH}$ is known to regulate bioactivity and availability of nutrients to plants, because $\mathrm{H}^{+}$protons are involved in chemical equilibrium. Jaggi et al. (2005) and Vicente et al. (2009) claimed that the availability of copper to plants, as with other trace minerals, markedly decreases as $\mathrm{pH}$ value rises. At high $\mathrm{pH}$ value copper is strongly adsorbed to clays, iron and aluminum oxides, and organic matter.

Elemental sulphur fertilization increased Mn concentrations in the soil, in comparison with the control. The application of $400 \mathrm{~kg}$ sulphur contributed to an increase in $\mathrm{Mn}$ content $\left(5.41 \mathrm{mgkg}^{-1}\right)$, compared with other sulphur doses. One of the adverse effects of sulphur contamination is an increase in Mn solubility and the mobilization of heavy metals from both natural and anthropogenic sources (Abdou et al., 2011).

Changes in $\mathrm{Zn}$ content of soil fertilized with elemental sulphur at a dose of 100,200 , and $400 \mathrm{~kg} / \mathrm{fed}$. were studied (Table 5). Before the experiment, zinc concentration is $0.5 \mathrm{mg} / \mathrm{kg}$ in the $0-0 \mathrm{~cm}$ soil layer (Table 1). At the end of the experiment, zinc concentrations in the soil ranged from 3.21 to $5.84 \mathrm{mg} / \mathrm{kg}$, irrespective of sulphur doses, and they were generally considerably lower than in the corresponding treatments. This could be due to increased bioavailability of zinc. Kayser et al. (2001) demonstrated that the application of elemental sulphur increased zinc solubility in the soil and utilization by plants. Different results were obtained by Abdou et al. (2011) who did not observe an increase in zinc availability to plants as a result of elemental sulfur fertilization.

Correlation analyses were carried out in order to determine which of the micronutrients uptake and soil characteristic $(\mathrm{pH})$ play the most important role in the uptake of the $\mathrm{Fe}, \mathrm{Cu}, \mathrm{Mn}$ and $\mathrm{Zn}$ by plant.

A significant positive correlation between soil $\mathrm{pH}$ and availability of nutrients as affected by sulphur levels. The relation is expressed by linear equations as follows:

$$
\begin{array}{lcc}
\text { Fe available: } & \mathrm{y}=-0.044 \mathrm{x}+8.611 & \mathrm{R}^{2}=0.88 \\
\mathrm{Cu} \text { available: } & \mathrm{y}=-0.302 \mathrm{x}+8.480 & \mathrm{R}^{2}=0.77 \\
\text { Mn available: } & \mathrm{y}=-0.076 \mathrm{x}+8.278 & \mathrm{R}^{2}=0.93 \\
\text { Zn available: } & \mathrm{y}=-0.081 \mathrm{x}+8.352 & \mathrm{R}^{2}=0.88
\end{array}
$$

Egypt. J. Soil Sci. 53, No. 4 (2013) 
Vicente et al. [2009] claim that the availability of copper to plants, as with other trace minerals, markedly decreases as $\mathrm{pH}$ value rises above save. At high $\mathrm{pH}$ value copper is strongly adsorbed to clays, iron and aluminum oxides, and organic matter. Of the micronutrients required by plants, $\mathrm{Cu}$ often has the lowest total concentration in soil.

In soils after plant harvest, micronutrients in soil were comparable, regardless of sulphur rates. A decrease in micronutrients content was recorded, compared with soil samples collected before the experiment, which could be due to micronutrients uptake by plants (Skwierawska et al., 2008). Correlation analyses were carried out in order to determine which of the micronutrients uptake and soil characteristics (available micronutrients) play the important role in the uptake of the $\mathrm{Fe}, \mathrm{Cu}, \mathrm{Mn}$ and $\mathrm{Zn}$ in the examined plant.

High positive correlation is found between availability of micronutrients and uptake of: $\mathrm{Fe}, \mathrm{Cu} \mathrm{Mn}$ and $\mathrm{Zn}$ for the different sulphur levels. The relationship is expressed by liner equations as follows :

Fe: $\quad \mathrm{y}=2.8941 \mathrm{x}+3.5664 \quad \mathrm{R}^{2}=0.77$

$\mathrm{Cu}: \quad \mathrm{y}=1.4904 \mathrm{x}+1.033 \quad \mathrm{R}^{2}=0.99$

$\mathrm{Mn}: \mathrm{y}=2.5939 \mathrm{x}-0.0299 \quad \mathrm{R}^{2}=0.85$

$\mathrm{Zn}: \quad \mathrm{y}=4.0204 \mathrm{x}-4.1684 \quad \mathrm{R}^{2}=0.72$

Nube and Voortman (2006) reported that good correlation between the plant contents of two micronutrients is depend on availability of these micronutrients and is controlled by the same soil factor (e.g., $\mathrm{pH}$ value of soil) or other soil factors. Smoleń et al. (2010) claimed that $\mathrm{Zn}, \mathrm{Mn}$ and $\mathrm{Fe}$ in plant correlated with $\mathrm{Zn}, \mathrm{Mn}$ and $\mathrm{Fe}$ in soil and $\mathrm{pH}$ value of soil. The $\mathrm{Zn}$ and $\mathrm{Mn}$ contents of plants decreased steadily with rising soil $\mathrm{pH}$ value.

Interactions

Organic fertilizers and elemental sulphur had a positive effect on the availability of micronutrients except $\mathrm{Mn}$ in soil. The higher availability of $\mathrm{Zn}$, $\mathrm{Mn}$ and $\mathrm{Cu}$ in soil was observed from Chicken manure and $400 \mathrm{~kg}_{\mathrm{s}} \mathrm{fed}^{-1}$ treatment. The high availability of $\mathrm{Fe}$ in soil was observed from Chicken manure and $100 \mathrm{~kg}_{\mathrm{s}} \mathrm{fed}^{-1}$ treatment. This higher availability might be due to elemental release from Chicken manure and to the affect of sulphur which reduced soil $\mathrm{pH}$. This makes make micronutrients more available.

\section{Conclusion}

In this paper the yield component, quality of carrots and trace elements uptake of carrot and some chemical properties is studied with different organic fertilizers and elemental sulphur rates. The highest yield of dry matter and nutrients uptake depend substantially on the interaction of the sulphur rate and kind of organic fertilizer. The highest values of dry mass, total soluble solid, Fe and $\mathrm{Cu}$ uptakes by roots and $\mathrm{Cu} \mathrm{Mn}$ and $\mathrm{Zn}$ available in soil were observed with application of chicken manure combined with sulphur at rate $400 \mathrm{~kg} \mathrm{fed}^{-1}$. 


\section{References}

Abdallah, M., Dubousset, L., Meuriot, F., Etienne, P., Avice, JC. and Ourry, A. (2010) Effect of mineral sulphur availability on nitrogen and sulphur uptake and remobilization during the vegetative growth of Brassicanapus L. J. Expt. Bot. 61(10): 23352346.

Abdou, A.S., Al Darwish, F.H. Saleh, M.E., El-Tarabily, K.A., Sofian-Azirun, M. and Monitor, R.M. (2011) Effects of elemental sulfur, phosphorus, micronutrients and Paracoccus versutus on nutrient availability of calcareous soils. Australian J. Crop Sci. 5: 554-561.

Allemann, L. and Young, B.W. (2002) Anintroduction to vegetable production. Nutrition, fertilisers, organic manures and compost making, 3rd edn.Department of Agriculture and Environmental Affairs, Pietermaritzburg, KwaZulu-Natal, South Africa. Analysis 36: 1823-37

Atkins, L. (1999) "Calcium Content of Raw Vegetables", United States Department of Agriculture, Agric.Res. Service, U.S.A.

Bokhtiar, S.M. and Sakurai, K. (2005) Integrated use of organic manure and chemical fertilizer on growth, yield and quality of sugarcanes in High Ganges River floodplain soils of Bangladesh. Soil Sci. Plant Analysis 36: 1823-37

Boyhan, G.E., Granberry, D., Kelley, W.T. and Mclaurin, W. (1999) Growing vegetables organically. The University of Georgia College of Agricultural and Environmental Sciences. Cooperative Extension Service. The University of Georgia Agricultural and Environmental Sciences, Georgia.

Chang, K.H., Wu, R.Y., Chuang, K.C., Hsieh, T. F. and Chung, R. S. (2010) Effects of chemical and organic fertilizers on the growth, flower quality and nutrient uptake of Anthurium andreanum, cultivated for cut flower production. Scientia Horticulturae 125: $434-441$

Chapman, H.D. and Pratt, P.F. (1978) "Methods of Analysis for Soils, Plant and Water", pp. 16-38, Univ. California Div., Agric. Sci.

Cox, L. and Koenig, T.R. (2010) "Solutions to Soil Problems: II High pH (Alkaline Soil)", United States University, Cooperative Extension, USA.

Cui, Y., Dong, Y., Kaifeng, Li. and Wang, Q. (2004) Effect of elemental sulfur on solubility of soil heavy metals and their uptake by maize. Environ. Intern. 30: 323 328.

Eshoo, T. and Bell, L.C. (1992) Soil and solution phase changes and mugg bean response during amelioration of aluminium toxicity organic matter. Plant Soil 140: 183-196.

Hue, N.V. and Amiens, I. (1989) Aluminium detoxification with green manures. Commun. Soil Sci. Plant Anal. 20: 1499-1511.

Egypt. J. Soil Sci. 53, No. 4 (2013) 
Jackson, M.L. (1973) "Soil Chemical Analysis", p.187, Prentice Hall India, Pvt. Ltd., New Delhi.

Jaggi, R.C., Aulakh, M.S. and Sharma, R. (2005) Impacts of elemental S applied under various temperature and moisture regimes on $\mathrm{pH}$ and available $\mathrm{P}$ in acidic, neutral and alkaline soils. Biol. Fertil. Soils 41: 52-58.

Kabata-Pendias, A. (2004) Soil-plant transfer of trace elements-an environmental issue. Geoderma 122 (2-4): 143-149.

Kaya, M., Küçükyumuk, Z. and Erdal, I. (2009) Effects of elemental sulfur and sulfur-containing waste on nutrient concentrations and growth of bean and corn plants grown on calcareous soil. African J. Biotech. 8: 448-449.

Kayser, A., Schroder, T.J., Grunwald, A. and Schulin, R. (2001) Solubilization and plant uptake of zinc and cadmium from soils treated with elemental sulfur. Inter. J. Phytoremediation 3: 381- 400

Landon, J.R. (1991) Booker tropical soil manual: "A Handbook for Soil Survey and Agricultural Land Evaluation in the Tropics and Sub-Tropics", p. 474, Longman Scientific and Technical, Essex, New York.

Levy, J.S. and Taylor, B.R. (2003) Effects of pulp mill solids and three composts on early growth of tomatoes. Bioresource Technology 89 (3): 297 - 305.

Lindsay, W.L. and Norvell, W.A. (1978) Development of a DTPA soil test for zinc, iron, manganese and copper. Soil Sci. Amer. J. 42 (3): 421- 428.

Lowther, J.R. (1980) Use of single $\mathrm{H}_{2} \mathrm{SO}_{4^{-}} \mathrm{H}_{2} \mathrm{O}_{2}$ disgest for the analysis of Pinus radiata, needles. Commun. Soil Sci. Plant Anal. 11: 175-188.

Martinez, C.E. and Motto, H.L. (2000) Solubility of lead, zinc of copper added to mineral soils. Environ. Pollu. 107: 153-158.

Marzouka, H. A. and Kassem, H. A. (2011) Improving fruit quality, nutritional value and yield of Zaghloul dates by the application of organic and / or mineral fertilizers. Scientia Horticulturae 127: 249-254.

Mateljan, G. (2007) The world's healthiest food. Nutrient in cabbage, shredded,boiled. George Mateljan Foundation, Chicago.

Natsher, M. and Schwetnmann, N. (1991) Proton buffering in organichorizons of acid forest soils. Geoderma 48: 93-106.

Niewhof, M., Debryun, J. W. and Carretsen, F. (1973) Methods to determine solidity and drymatter of onion (Allium cepa L.). Euphytica 22 : 39-47.

Nube, M. and Voortman, R.L. (2006) Simultaneously addressing micronutrient deficiencies in soils, crops, animal and human nutrition: opportunities for higher yields and better health. Staff Working Paper WP-06-02. Stichting Onderzoek Wereldvoedselvoorziening van de Vrije Universiteit. Centre for World Food Studies. $1-41$. 
Orman, Ş. and Kaplan, M. (2011) Effects of elemental sulphur and farmyard manure on $\mathrm{pH}$ and salinity of calcareous sandy loam soil and some nutrient elements in tomato plant. J. Agric. Sci. Technol. 5 (1): 20-26.

Page, A.L., Miller, R.H. and Keeney, D.R. (1982) "Methods of Soil Analysis", Part 2, $2^{\text {nd }}$ ed., pp. 98-765, American Society of Agronomy Inc., Medison, Washington, USA.

Pitman, S. and Signh, K.A (1993) Effect of continous application of manure and nitrogenous fertilizers on the properties of acid Inceptisol. J. Indian Soc. Soil Sci. 41: 430-433.

Pocknee, S. and Sumner, A. (1997) Cation and nitrogen contents of each of organic matter determines its liming potential. Soil Sci. Soc. Am. J. 61: 86-96.

Rasoli, S. and Forghani, A. (2006) Effect of organic manure on micronutrient availability in different soils. $18^{\text {th }}$ World Congress of Soil Science, Philadelphia, Pennyslvania.

Rembialkowska, E. (2003) Organic farming as a system to provide better vegetable quality. Acta Hortic. 604: 473 - 479.

Rosen, C.J. and Bierman, P.M. (2005) Using manure and compost as nutrient sources for fruit and vegetable crops. Department of Soil, Water and Climate Sciences, University of Minnesota.

Scherer, H.W., Pacyna, S., Spoth, K.R. and Schulz, M. (2008) Low levels of ferredoxin, ATP, and leghemoglobin contribute to limited N2 fixation of peas (Pisum sativum L.) and alfalfa (Medicago sativa L.) under S deficiency conditions. Biol. Fertil. Soil 44: 909-916.

Skwierawska, M., Zawartka, L. and Zawadzki, B. (2008) The effect of different rates and forms of sulfur applied on changes of soil agrochemical properties. Plant, Soil Environ. 54: 171-177.

Smith, B.L. (1993) Organic foods vs. Supermarket foods: Element levels. J. Appl.Nutr. 45,1 .

Smoleń, S., Sady, W. and Ledwożyw-Smoleń, I. (2010) Quantitative relations between the content of selected trace elements in soil extracted with $0.03 \mathrm{MCH} 3 \mathrm{COOH}$ or 1 $\mathrm{M} \mathrm{HCl}$ and its total concentrationin carrot storage roots. Acta Sci. Pol., Hortorum Cultus 9 (4): 3-12.

Steel, RGD and Torrie, JH. (1980) "Principles and Procedures of Statistics", $2^{\text {nd }}$ ed., MC. Grow. Hill, New York.

Suojala, T. (2003) Compositional and quality changes in white cabbage during harvest period and storage. J. Hort. Sci. Biotech. 78(6): 821827.

Tai, Y.P. and Young, G.P., (1974) Variation in protein percentage in different portions of peanut cotyledons. Crop Sci. $14: 222-229$.

Egypt. J. Soil Sci. 53, No. 4 (2013) 
Takáč, P., Zabová, S.T., Kozáková, L. and Benková, M. (2009) Heavy metals and their bioavailability from soils in the long-term polluted Central Spiš region of SR. Plant, Soil Environ. 55: 167-172.

Vicente, A.R., Manganaris, G.A., Sozzi, G.O. and Crisisto, C.H. (2009) Postharvest Handing: A Systems Approach. In: "Nutritional Quality of Fruits and Vegetables". W.J. Florkowski, R.L. Shewfelt, R. Brueckner and S.E. Prussia (Ed.), Elsevier INC., pp. 81-86.

Walker, D.J., Clemente, R. and Bernal, M.P. (2004) Contrasting effects of manure and compost on soil $\mathrm{pH}$, heavy metal availability and growth of Chenopodium album L. in a soil contaminated by pyritic mine waste. Chemosphere 57: 215-224

Wong, J.W.C., MA, K.K., Fang, K.M. and Cheung, C. (1998) Utilization of a manure compost for organic farming in Hong Kong. Br. Tech. 7: 43 - 46.

Worthington, V. (1998) Effect of Agricultural methods on nutritional quality: A comparison of organic with conventional crops. Alternative Therapies 4: $58-69$.)

Xu, H.L., Wang, R., XU, R.Y., Mridha, M.A.U. and Goyal, S. (2003) Yield and quality of leafy vegetables grown with organic fertilizers. Acta Hortic. 627: 25 - 33

Zakaria, A. and Vimala, P. (2002) Research and development of organic crop production in Malaysia. FAO Expert Group Workshop on Preparation of Technical Guidelines on Organic Cultivation of Tropical and Subtropical Fruits. Intan Bukit Kiara, Kuala Lumpur.

Zane, F.L. and Basil, D.D. (1980) Residual effects of dairy cattle manure on plant growth and soil properties. Agron. J. 72: 123-30. 


\section{محصول و جودة و الممتص من العناصر الصغرى للجزر و بعض بوض

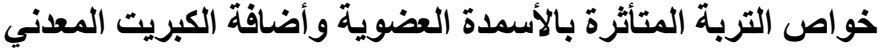 \\ وفاء حسن محمد \\ قسم الأراضي و الكيمياء الزراعية ـ كلية الزر اعة (سابا بانثا) - جامعة الأسكندرية ـ

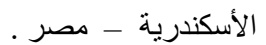

أجريت تجربة حقلية بمزر عة كلية الزر اعة - سابا بانشا- جامعة الاسكندرية خلال

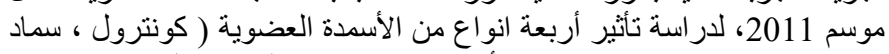

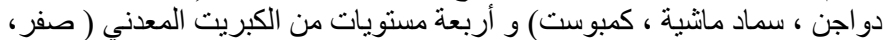

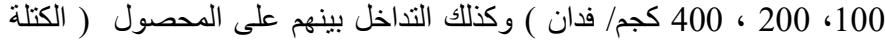

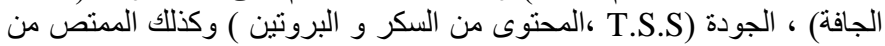

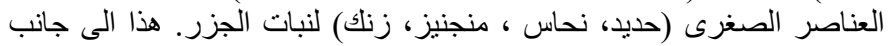

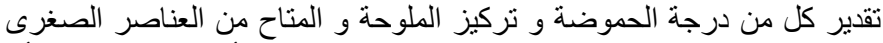

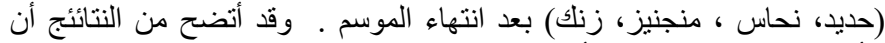

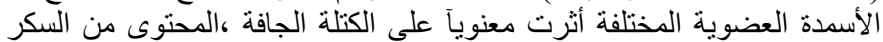

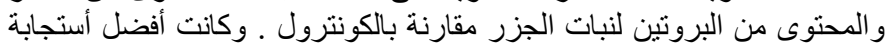
بأضافة سماد دو اجن يتبعها سماد ماثنية ثم الكمبوست.

وأدت الأسمدة العضوية المستخدمة الى زيادة معنوية للممنص من العناصر

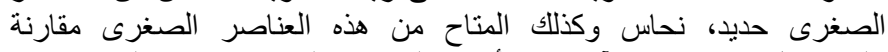

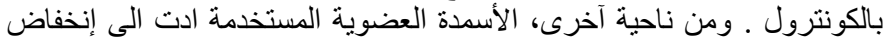
معنوي في كل من درجة الحموضة و تركيز الملوحة (ماعدا سماد الدواجن).

وأدت أضافة مستويات من الكبريت المعدني الى زيادة معنوية لكل من الكتلة الكنا

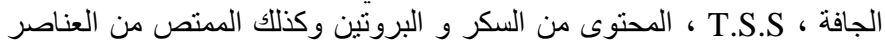

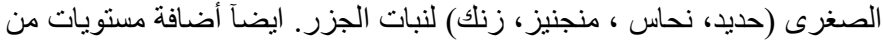

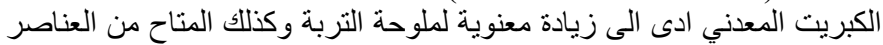

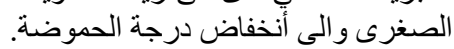

و أفضل أستجابة لنبات الجزر تعتمد على التداخل بين مستوي الكبريت ونوع الجناف

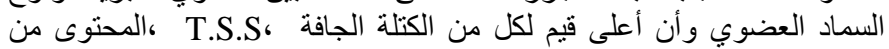

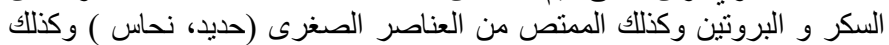

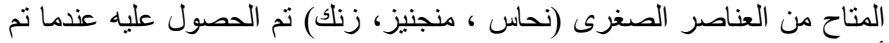

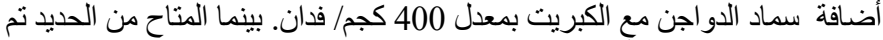
الحصول عليه عندما تم أضافة سماد الدواجن مع الكبريت بمعدل 100 كجم/ فدان.

أجريت أيضاً تحليلات الأرتباط من أجل تحديد أي من المغذيات الدقيقة

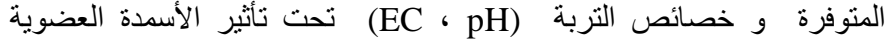
ومستويات الكبريت المختلفة و التي تلعب دور هام في امتصاص كل من من النحاس، الحديد، المنجنيز و الزنك في النبات المختبر. 